\title{
A combined dietary approach using isotope and dental buccal-microwear analysis of human remains from the Neolithic, Roman and Medieval periods from the archaeological site of Tossal de les Basses (Alicante, Spain)
}

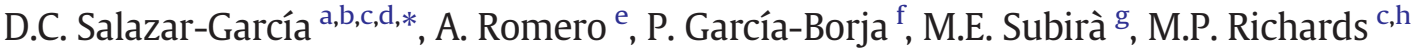 \\ a Department of Archaeology, Faculty of Science, University of Cape Town, South Africa \\ b Department of Human Evolution, Max-Planck Institute for Evolutionary Anthropology, Leipzig, Germany \\ c Departament de Prehistòria i Arqueologia, Facultat de Geografia e Història, Universitat de València, Spain \\ d Department of Archaeogenetics, Max-Planck Institute for the Science of Human History, Jena, Gemany \\ e Departamento de Biotecnología, Facultad de Ciencias, Universidad de Alicante, Spain \\ ${ }^{\mathrm{f}}$ Universidad Nacional de Educación a Distancia, Valencia, Spain \\ g GRAPAC, Unitat d'Antropologia Biològica, Facultat de Biociències, Universitat Autònoma de Barcelona, Spain \\ ${ }^{\mathrm{h}}$ Department of Anthropology, University of British Columbia, Vancouver, Canada
}

\section{A R T I C L E I N F O}

\section{Article history:}

Received 2 September 2015

Received in revised form 10 February 2016

Accepted 1 March 2016

Available online xxxx

\section{Keywords:}

Carbon

Nitrogen

Dental-microwear

Diet

Human

Iberia

\begin{abstract}
A B S T R A C T
Stable isotope and dental-microwear analysis are methods commonly used to reconstruct dietary habits in modern and ancient human populations. However, it is rare that they are both used together in the same study, and here both methods are combined to obtain information on human dietary habits from the site of Tossal de les Basses (Alicante, Spain) through time. Middle Neolithic, Late Roman and Medieval (Islamic) individuals have been analyzed for carbon and nitrogen stable isotope ratios of bone collagen, as well as for buccal-dental microwear. Overall, $\delta^{13} \mathrm{C}$ and $\delta^{15} \mathrm{~N}$ isotopic values show that for all periods the diet was mainly based on $\mathrm{C}_{3}$ terrestrial resources. However, the isotopic signature suggests a small, but clear amount of marine protein consumption during the Neolithic period and possibly also for a few individuals from the Medieval period. When compared to other studies from the region, it is also possible to see that the consumption of $C_{4}$ resources was much more extensive during Medieval times than in previous periods. Microwear scratch density and length found for teeth from the Neolithic and Medieval periods reflect a diet in which tough foods predominated, requiring substantial pressure to chew in comparison with what was recorded for the Roman individuals. Combined with the $\delta^{15} \mathrm{~N}$ data, the microwear signature suggests a higher input of marine/gritty resources among the Neolithic and Medieval populations compared to the Romans. Our findings also suggest that dietary patterns might be explained by cultural and technological population factors rather than habitat resource availability.
\end{abstract}

(c) 2016 Elsevier Ltd. All rights reserved.

\section{Introduction}

Both stable isotope and dental-microwear studies are commonly used methods for past human dietary reconstructions (Larsen, 1997). The application of these analytical techniques in Mediterranean Iberia has significantly increased during the past few years, creating an important corpus of dietary data from the region. Studies from the Palaeolithic (García-Guixé et al., 2009; Salazar-García et al., 2013a), Mesolithic (Fernández-López de Pablo et al., 2013; García-Guixé et al., 2006; Salazar-García et al., 2014a), Neolithic-Chalcolithic (Fontanals-Coll et al., 2015; Fuller et al., 2010; García-Borja et al., 2013; McClure et al., 2011; Romero and De Juan, 2004, 2007; Salazar-García, 2009, 2011a, 2014), Bronze Age (McClure et al., 2011; Polo-Cerdá et al., 2007; Romero and De Juan, 2007), Iron Age (Salazar-García et al., 2010),

\footnotetext{
* Corresponding author at: Department of Archaeology, University of Cape Town, South Africa.

E-mail address: domingocarlos.salazar@uv.es (D.C. Salazar-García).
}

Punic (Fuller et al., 2010; Salazar-García, 2011b), Roman (Fuller et al., 2010) and Medieval (Alexander et al., 2015; Fuller et al., 2010; Salazar-García et al., 2014b) periods have been performed in Mediterranean Iberia and the nearby island of Ibiza. However, to date only a few studies have had a wide diachronic approach to diet in Spain (see Fuller et al., 2010; Salazar-García et al., 2013b).

On the other hand, stable carbon and nitrogen isotopes have also been used to elucidate skeletal stress indicators in ancient human remains (see Richards and Montgomery, 2012; for a review of cases studied). Nonetheless, in contrast to the information regarding the exploitation of plants and animals as potential food sources, the use of isotopic signatures does not allow to learn properly about specific diseases, because their link is not exclusively caused by diet (Katzenberg, 2012; Reitsema, 2013). Specifically, isotopic data in ancient populations from Mediterranean Iberia are often presented in isolation from other complementary evidence such as skeletal or dental pathological conditions (e.g. Fernández-López de Pablo et al., 2013; Fontanals-Coll et al., 
2015; McClure et al., 2011), since these methods offer complementary but different insights into dietary reconstruction (Larsen, 1997; Hogue and Melsheimer, 2008). Moreover, although early reports have combined isotopic signatures and occlusal-dental microwear in past human populations as a means of dietary reconstruction (Hogue and Melsheimer, 2008; Lillie and Richards, 2000), this combined approach applied to buccal dental-microwear is still scarce (García-González et al., 2015).

Here, carbon and nitrogen stable isotope and buccal dental-microwear analyses are integrated to assess dietary transitions from three chronological populations, dating from Neolithic to Medieval periods, recovered from the Tossal de les Basses site (Alicante, Spain).

\subsection{The archaeological-historical context}

The first archaeological evidence of Neolithic economic and technological activities in coastal Eastern Iberia (Catalonia and Valencia) are documented around 5600 cal BCE (Table 1). In this chronological context, the transition from the hunter-gatherer lifestyle to a farmingherding one is associated with a coastal demic diffusion process (Zilhão, 2001). The choice of the areas where the earliest farmers settled often corresponds to places where there is no presence of late huntergatherers (Martí et al., 2009). Furthermore, there is no clear evidence of Mesolithic groups adopting agriculture or herding practices in the Valencian Country (Fernández-López de Pablo et al., 2013), nor in Catalonia (Morales and Oms, 2012).

Early farming groups that settled in Eastern Iberia are grouped with the so-called Impressed Ware cultures of the Western Mediterranean, more specifically the "cardial" phase (Martí and Juan-Cabanilles, 2014). The start of the Middle Neolithic period is contemporary with the end of the cardial period, and resulted in important changes that go beyond the mere disappearance of the pottery decoration technique. New agrarian and herding models aimed at the increasing production are developed then (Pérez Jordà and Peña Chocarro, 2013), resulting in changes in the habitat structures and the new use of caves (Badal et al., 2012). These changes were consolidated during the Late Neolithic and Chalcolithic periods (Bernabeu and Orozco, 2014), resulting in settlements increasing in size whose main feature is the high occurrence of silos purportedly for

Table 1

Regional chronologies relevant to the Tossal de les Basses site.

\begin{tabular}{ll}
\hline PERIOD (circa cal BCE-CE) & Phase (circa cal BCE-CE) \\
\hline MESOLITHIC (6000-5600 BCE) & Notches-denticulates (7500-6600 BCE) \\
NEOLITHIC (5575-2800 BCE) & Early (5575-4850 BCE) \\
& Middle (4850-3800 BCE) \\
& Late (3800-2800 BCE) \\
CHALCOLITHIC (2800-2150 BCE) & Pre-Bell Beaker (2800-2500 BCE) \\
& Bell Beaker (2500-2150 BCE) \\
BRONZE AGE (2150-750 BCE) & Ancient (2150-1900 BCE) \\
& Middle (1900-1500 BCE) \\
& Advanced (1500-1200 BCE) \\
& Final (1200-750 BCE) \\
IRON AGE (750-218 BCE) & Phoenician colonies (750-550 BCE) \\
& Ancient Iberian culture (550-450 BCE) \\
ROMAN HISPANIA (218 BCE-395 CE) & Iberian culture (450-218 BCE) \\
Republic (218-27 BCE) \\
High Empire (27 BCE-284 CE) \\
Late Empire (284-395 CE) \\
LATE ANTIQUITY (395-711 CE) & Visigoths and Byzantine \\
ISLAMIC (711-1248 CE) & Islamic Emirate (711-929 CE) \\
& Islamic Caliphate (929-1010 CE) \\
& Taifas and Almoravids (1010-1145 CE) \\
Almohads and Taifas (1145-1248 CE) & Kingdom of Castilla (1248-1296 CE) \\
LATE MIDDLE AGES (1248-1609 CE) & Crown of Aragón (1296-1492 CE) \\
\hline
\end{tabular}

a Although Phoencians are normally considered one of the Ancient classical civilizations, we have included them here within the broad classification of "Iron Age" because in the Iberian peninsula the establishment of the Phoenician colonies and the appearance of characteristic Phoenician artifacts coincides with the start of Iron Age in this region. grain storage. This changes again in the Bronze Age when the population is divided into small groups and occupies wider extensions of territory including high altitude areas (Hernández and Hernández, 2004).

In addition, commercial contacts start increasing in the region in the Bronze Age. These commercial networks are mainly based in the Mediterranean, and finally resulted in the establishment of Phoenician (Valencian Country and Ibiza) and Greek (Catalonia) colonies whose interaction with local peoples led to the formation of the Iberic Iron Age Culture (Ruiz and Molinos, 1993; Knapp and Van Dommelen, 2015). This Iron Age culture had an important presence in Eastern Iberia and actively participated in the historical and economical processes of the Western Mediterranean at this time (Vives-Ferrándiz, 2008). A good example of this is the participation in the Second Punic War by the Iberic Iron Age People, which resulted in the progressive integration of the Roman Republic within their cities and villages between the 6th and 2nd centuries BCE (Aranegui et al., 1998).

From this period onwards, the Mediterranean coast became part of Roman Hispania, and the history of its territories was closely linked to those of Rome (Tovar and Blázquez, 1997; Arce Martínez et al., 2007). After the beginning of the disintegration of the Western Roman Empire in $409 \mathrm{CE}$, a convulsive period marked by the arrival of the Visigoths started. This resulted in the formation of the Visigoth Kingdom of Toledo, which consolidated its influence on Eastern Iberia during the 6th century $\mathrm{CE}$, regardless of the constant battle clashes in its coastal territories with Byzantine troops (García-Moreno, 1989; Vizcaíno-Sánchez, 2007). The old political map of ancient Hispania finally collapsed from 711 CE onwards with the arrival of new troops from the North-African coasts. These people crossed the Gibraltar Strait and conquered most of the Iberian Peninsula, which became known as Al-Andalus under Islamic rule (González-Ferrín, 2007).

Meanwhile, in northeast Iberia during the 10th century CE the consolidation of the Kingdom of Aragón and the County of Barcelona occurred. The union of both in 1164 with the coronation of Alfonso II of Aragón resulted in the emergence of the so-called Crown of Aragón (Belenguer, 2007). This political entity expanded progressively towards the south by occupying Islamic territory. During the first half of the 13th century CE, King Jaume I conquered the Kingdoms of Valencia and Mallorca and incorporated them into the Crown of Aragón. These two territories retained certain independence after being granted royal privileges that were only removed in $1707 \mathrm{CE}$. After this conquest, the Islamic population was integrated in the Christian feudal lifestyle until their final expulsion in 1609 CE (Furió, 2001).

\subsection{The site studied: Tossal de les Basses}

The archaeological site of Tossal de les Basses is located on a wetland north of the city of Alicante (Spain), along the coastline (Fig. 1). Several excavations have revealed human occupation from different chronological periods: Middle and Late Neolithic, Iberian Iron Age, Republican and Late Roman, Medieval (Islamic and Christian), and Modern periods (Rosser, 2012; Rosser and Fuentes, 2007). This long history of occupation makes Tossal de les Basses an invaluable place for investigating changes in dietary behavior through time.

The first evidence of human presence found at Tossal de les Basses has been dated to the Neolithic period, between ca. 4900-3500 cal BCE (Rosser, 2010). These early remains are those of a village and include huts with a circular layout, pits, ditches, hearths and basins. Close to the domestic space and outside the huts, 15 human scattered burials have been found (Rosser, 2010). The bodies were interred individually in shallow circular pits in a lateral decubitus position. Some of these burials include grave goods such as beads, shells or pots placed besides the head.

The Roman occupation phase at the site is divided into two different periods. The oldest one is associated with a series of villae established at Tossal de les Basses as a result of the increasing importance that the nearby city of Lucentum acquired at the time (it had the juridical rank of municipium since the last quarter of the 1st century BCE). Secondly, the 


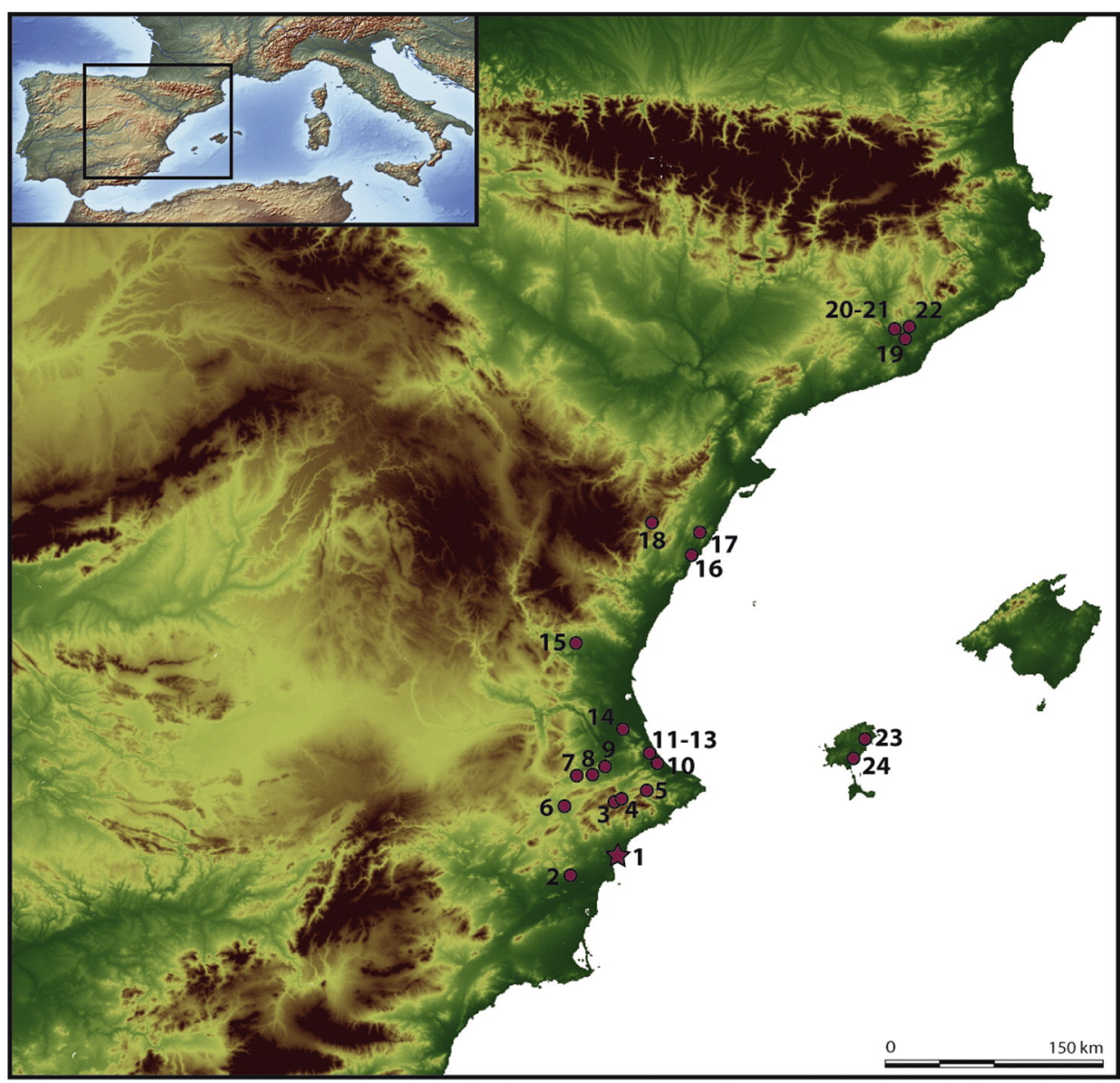

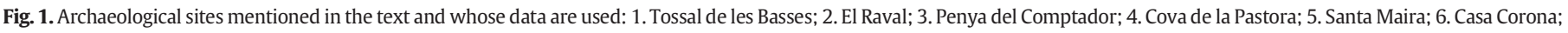

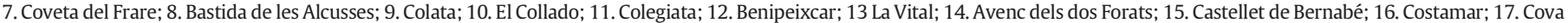
dels Diablets; 18. Cingle del Mas Nou; 19. Bòbila Madurell; 20. Can Gambús; 21. Can Roqueta-Can Revell; 22. Horts de Can Torras; 23. Can Marines; 24. Ibiza.

most recent Roman occupation phase corresponds to the 6th-7th century CE necropolis found with hundreds of inhumations. The bodies where individually buried in rectangular graves covered by stone blocks. Most of these bodies were found without grave goods (Rosser and Fuentes, 2007).

Just besides this Late Roman necropolis, several burials with special characteristics appear. Although sharing morphology and area with the Late Roman ones, the bodies buried in these ones follow the Muslim ritual with body in lateral decubitus position with the heads facing towards Mecca. The chronology proposed for these Islamic inhumations is from the 8th to 9th centuries CE (Laguillo et al., 2009).

\subsection{Stable isotopes and buccal-microwear in dietary reconstructions}

The isotopic composition of the food eaten by both animals and humans is recorded in their body tissues after a predictable isotope fractionation, and is the main principle on which carbon and nitrogen stable isotope studies are based (e.g. Lee-Thorp, 2008; Schoeller, 1999). For these analyses bone collagen is usually the preferred substrate, mainly because it is the only considerable nitrogen source from skeletal remains (Salazar-García et al., 2014b) and has accepted quality indicators that can easily assess its isotopic integrity (De Niro, 1985; Van Klinken, 1999). Stable isotope ratios in bone collagen reflect the average isotopic signals of the main dietary protein sources consumed several years prior to death (Hedges et al., 2007).

The $\delta^{13} \mathrm{C}$ stable isotope ratio distinguishes the consumption of $\mathrm{C}_{3}$ (lower values) and $\mathrm{C}_{4}$ (higher values) terrestrial resources (Van der Merwe and Vogel, 1978). Isotopic signals also help define the input in the diet of terrestrial (lower values) and marine (higher values) foods (Chisholm et al., 1982), although interpretation of $\delta^{13} \mathrm{C}$ values becomes more complicated if involving freshwater or estuarine fish (SalazarGarcía et al., 2014a). Parallel to this, the $\delta^{15} \mathrm{~N}$ stable isotope ratio increases by $3-5 \%$ o up the food-chain with each trophic level, and is usually used to indicate the position of an organism in the food chain (Minagawa and Wada, 1984). Based on the exact values of the nitrogen ratio, it is potentially possible to differentiate between individuals that consumed more animal resources from those who consumed very little animal proteins (Fahy et al., 2013), even if this quantification is less straightforward than previously thought (Hedges and Reynard, 2007). Furthermore, the fact that aquatic food chains tend to contain more trophic levels than terrestrial ones helps carbon isotope ratios to discriminate between the consumption of marine or $\mathrm{C}_{4}$ terrestrial foods when samples are ${ }^{13} \mathrm{C}$ enriched (Schoeninger and De Niro, 1984). However, this type of analysis on bone collagen has some methodological limitations: it gives information only on protein consumption, and refers to the average of the last years of life of the individual (Katzenberg, 2012).

Buccal dental-microwear refers to microscopic-scale tooth wear on non-occlusal enamel surfaces of premolar and molar teeth (Pérez-Pérez et al., 1994; Romero et al., 2012). Microscopic enamel damage in the form of scratches of different length is directly related to contact with food abrasive objects harder than enamel such as opal phytoliths or grit contaminants during chewing (Pérez-Pérez et al., 1994; Romero and De Juan, 2012). Experimental in vivo reports have recently shown that the teeth of humans who ate soft foods have fewer microwear features than those individuals consuming an induced-abrasive diet (Romero et al., 2012). Therefore, dietary abrasiveness plays an important role in tooth-microwear formation processes. However, buccal microwear patterns reflect the physical properties of chewed foodstuffs and long-term trends in dietary 
preferences (Pérez-Pérez et al., 1994; Romero et al., 2012) but not the type of foods ingested (Romero and De Juan, 2012).

Studies in human populations have shown that intragroup buccalmicrowear variation seems to be less significant than inter-individual and inter-group variability (Pérez-Pérez et al., 1994; Lalueza et al., 1996; Romero and De Juan, 2007), since the amount and physical properties of abrasive particles in the diet determine the microwear formation rates (Gügel et al., 2001; Romero et al., 2012, 2013). For example, farming groups that eat more abrasive items (e.g. milled cereals) mostly show high microwear density values (Romero and De Juan, 2007, 2012). Foragers consuming large amounts of meat and non-abrasive plant materials show lower scratch density values on buccal enamel surfaces (Lalueza et al., 1996; Polo-Cerdá et al., 2007; Romero et al., 2013). Nonetheless, microwear models and selected human groups for comparison are still necessary, since little is known about how buccal-microwear reflects cultural and ecological factors among populations that inhabit similar environmental conditions.

By combining both carbon and nitrogen isotopes and dentalmicrowear techniques, here we record the complex interaction by the types of food consumed and their texture from the diachronic populations documented at the Tossal de les Basses site. We aim to obtain a more finegrained approach of dietary reconstruction among ancient human groups, with special attention to those dietary changes that occur between prehistoric and historic periods in the Iberian Peninsula.

\section{Material and methods}

\subsection{Human skeletal sample}

In this study, archaeological human skeletal samples ( $n=85)$ were selected from the Tossal de les Basses excavated site (Rosser and Fuentes, 2007). This project focused only on adult individuals ( $\geq 18$ years). Individual age and sex was estimated based on both nonmetric and metric physical-anthropological methods, using a combination of cranial and post-cranial information when available, and following internationally recognized standards (Buikstra and Ubelaker, 1994; Murail et al., 2005; Schmitt, 2005).

Bone samples from a total of 61 individuals from all time periods available at Tossal de les Basses were sampled for isotope analysis. The samples correspond to 11 individuals from the Middle Neolithic period, 36 from the Late Roman period, and 14 from the Medieval period. Bone samples selected were mainly ribs, except in those few cases in which they were not available or because their provenance was unclear, in which case identified long bones or skull fragments were sampled.

Buccal-microwear data were collected from a total of 40 individuals of the Middle Neolithic $(n=8)$, Late Roman $(n=26)$, and Medieval $(n=6)$ chronological periods. One tooth per individual, preferably in situ mandibular fourth premolar $\left(\mathrm{P}_{4}\right)$ or first molar $\left(\mathrm{M}_{1}\right)$ teeth, were selected (Pérez-Pérez et al., 1994; Lalueza et al., 1996). The use of mandibular premolar or molar teeth with the best microwear preservation is a common procedure used for the purpose of comparing buccal-microwear among groups (Lalueza et al., 1996; Romero and De Juan, 2012). Early reports indicate no significant differences between these teeth in microwear density and length variables in forager (Lalueza et al., 1996) or agriculturalist (Pérez-Pérez et al., 1994) populations.

\subsection{CN isotope analysis}

Collagen extraction for $\mathrm{C}$ and $\mathrm{N}$ isotope analysis proceeded following methods outlined in Richards and Hedges (1999). Whole bone fragments weighing ca. $300 \mathrm{mg}$ obtained from each of the fragments were demineralized in $0.5 \mathrm{M} \mathrm{HCl}$ solution at $5{ }^{\circ} \mathrm{C}$ over the course of one week, and were then rinsed three times with deionized water until the $\mathrm{pH}$ became neutral. This was followed by gelatinization over $48 \mathrm{~h}$ at $70{ }^{\circ} \mathrm{C}$, and then filtering and ultrafiltering using a 50-90 $\mu \mathrm{m}$ EZEE@ filters, and previously cleaned $>30 \mathrm{kDa}$ Amicon@ ultrafilters, respectively. The purified solutions were frozen and lyophilized before being weighed into tin capsules and loaded onto the mass spectrometers.

The carbon and nitrogen isotope ratios in collagen were measured in duplicate, using a Delta XP continuous-flow isotope ratio mass spectrometer interfaced with an elemental analyzer, Flash EA 2112 (ThermoFinnigan $\odot$, Bremen, Germany), at the MPI-EVA (Leipzig, Germany). Stable carbon isotope ratios were expressed relative to the VPDB scale (Vienna PeeDee Belemnite) and stable nitrogen isotope ratios were measured relative to the AIR scale (atmospheric $\mathrm{N}_{2}$ ), using the delta notation $(\delta)$ in parts per thousand (\%o). Repeated analysis of internal and international standards determined an analytical error better than $0.2 \%$ 。 $(1 \sigma)$ for $\delta^{13} \mathrm{C}$ and $\delta^{15} \mathrm{~N}$.

Although no animal remains were available from the chronological periods associated with the human remains studied at Tossal de les Basses, we used faunal data from other sites of Eastern Iberia and Ibiza for the Middle-Late Neolithic (Fontanals-Coll et al., 2015; Salazar-García, 2009, 2011a, 2014), Roman (Fuller et al., 2010; Salazar-García et al., 2010) and Medieval (Alexander et al., 2015; Fuller et al., 2010) periods. Animal isotopic values were grouped together as ovicaprid, suid, bovid, equid, cervid, rabbit, small carnivore, dogs, cat, bird, shark and whale.

\subsection{Analysis of buccal-microwear}

High-resolution replicas from the selected teeth were made following established procedures (Galbany et al., 2006). Tooth crowns were cleaned with cotton swabs soaked with ethyl alcohol and distilled water, and later air-dried. Dental impressions were made using President microSystem Regular body (Coltène-Whaledent ${ }^{\circledR}$ ) polyvinylsiloxane, and resulting replicas were produced using epoxy polymer (Araldite ${ }^{\circledR} 2020$, Vantico Ltd.) and hardener. The sample analyzed included only replicas examined under light microscopy $(50 \times)$ that showed well-preserved enamel with ante-mortem microwear features (Romero and De Juan, 2012). Trampling processes are generally easily detected on buccal-enamel surfaces (Romero and De Juan, 2012). Previous studies have demonstrated that post-mortem effects produce micro-damages that are clearly different to ante-mortem microwear affecting tooth surfaces through food abrasive particles ingested (Romero and De Juan, 2004, 2007).

All replicas were then mounted on aluminum stubs, coated with a $\sim 15$-nm layer of gold-palladium, and analyzed using Scanning Electron Microscopy (SEM) using an Hitachi S3000N SEM. Micrographs $(1280 \times 960$ pixels $)$ were taken at $100 \times$ magnification in the middle third of the buccal tooth surfaces, automatic level adjusted and cropped with Adobe Photoshop ${ }^{\mathrm{TM}}$ to cover exactly $0.56 \mathrm{~mm}^{2}$ (Galbany et al., 2005). Scratch density (NT) and average length (XT) (in micrometers, $\mu \mathrm{m}$ ) of all observed lineal scratches $>10 \mu \mathrm{m}$ were recorded and measured for each micrograph with Sigma Scan ProV SPSS ${ }^{\text {тM }}$ (Galbany et al., 2005).

\subsection{Statistical analysis}

Given the small sizes of some chronological groups, data were normalized by rank-transformation to mitigate effects of non-colinearity of variable distribution and heteroscedasticity (Conover and Iman, 1981; Romero et al., 2013). All the variables studied passed Kolmogorov-Smirnov normality tests for both microwear $(Z=0.42$ to 0.49 ; $P>0.05)$ and isotopic values $(Z=0.88$ to $1.01 ; P>0.05)$.

Age and sex-related changes were not taken into account, especially since this study is limited to adult individuals ranging from between approximately age 18 to 50 , and because of the high number of individuals where sex was not determined. Likewise, early reports have shown that neither age (young adult or adult age groups) nor sex-related differences in buccal scratch patterns are detectable (Lalueza et al., 1996; Pérez-Pérez et al., 1994; Romero and De Juan, 2007). Moreover, 
regarding isotopic signals, sex differences, where identified, may actually reflect differing patterns and levels of male and female mobility rather than diet (Müldner, 2013).

Single classification of variance (ANOVA) and paired comparisons using Tukey's Honest Significant Difference test (Tukey's HSD) were performed to check inter-population differences in microwear patterns. Finally, an Analysis of Covariance (ANCOVA) and Reduced Major Axis (RMA) regressions were used as needed to analyze the isotopicmicrowear interaction and differences among chronological periods. Descriptive and statistical analyses at the $\alpha=0.05$ significance level were conducted using Addinsoft ${ }^{\text {TM }}$ XLSTAT-3.02.

\section{Results}

\subsection{Stable isotope analysis}

The carbon and nitrogen stable isotope ratio results for the humans from Tossal de les Basses are presented in Table 2 and illustrated in Fig. 2. All human samples yielded sufficient collagen in the $>30 \mathrm{kDa}$ fraction for analysis in duplicate, except samples 11,350 (10-30 kDa fraction used) and 11,371 ( $<10 \mathrm{kDa}$ fraction used). All of them met published collagen quality controls (i.e. C:N ratio between 2.9 and 3.6 - De Niro, 1985; Van Klinken, 1999) (Table 2).

Table 2

Carbon and nitrogen isotope ratio values, and collagen quality indicators, from all humans studied at Tossal de les Basses.

\begin{tabular}{|c|c|c|c|c|c|c|c|c|c|}
\hline S-EVA & Period & UE & Sex & Age (years) & $\delta^{13} \mathrm{C}(\%)$ & $\delta^{15} \mathrm{~N}(\%)$ & $\% C$ & $\% \mathrm{~N}$ & $\mathrm{C}: \mathrm{N}$ \\
\hline 11,358 & Middle Neolithic & 11,004 & Indet. & $24-35$ & -18.0 & 11.6 & 19.7 & 6.4 & 3.6 \\
\hline 11,359 & Middle Neolithic & 11,525 & Indet. & $40-45$ & -17.5 & 13.1 & 39.0 & 13.7 & 3.3 \\
\hline 11,360 & Middle Neolithic & 11,549 & Indet. & $24-35$ & -18.6 & 11.1 & 38.7 & 13.4 & 3.4 \\
\hline 11,361 & Middle Neolithic & 11,709 & Indet. & $24-35$ & -19.0 & 10.8 & 35.3 & 12.2 & 3.4 \\
\hline 11,362 & Middle Neolithic & 11,409 & Female & $25-45$ & -17.5 & 12.9 & 38.2 & 13.5 & 3.3 \\
\hline 11,363 & Middle Neolithic & 13,118 & Indet. & $45-55$ & -18.0 & 10.5 & 29.7 & 10.1 & 3.4 \\
\hline 11,364 & Middle Neolithic & 11,022 & Indet. & $24-30$ & -17.7 & 10.4 & 24.5 & 8.0 & 3.6 \\
\hline 11,366 & Middle Neolithic & 11,724 & Indet. & $35-45$ & -19.1 & 9.0 & 23.5 & 7.9 & 3.5 \\
\hline 11,370 & Middle Neolithic & 11,471 & Indet. & $24-35$ & -17.7 & 10.5 & 36.3 & 13.0 & 3.3 \\
\hline 11,371 & Middle Neolithic & 1707 & Male & $25-35$ & -17.6 & 12.4 & 41.7 & 15.3 & 3.2 \\
\hline 11,372 & Middle Neolithic & 1819 & Female & $35-45$ & -18.0 & 10.8 & 35.3 & 12.1 & 3.4 \\
\hline 11,318 & Late Roman & 9037 & Male & $20-30$ & -18.3 & 9.2 & 38.8 & 14.0 & 3.2 \\
\hline 11,319 & Late Roman & 7010 & Male & $45-49$ & -18.0 & 11.1 & 41.0 & 14.8 & 3.2 \\
\hline 11,320 & Late Roman & 9067 & Male & $24-35$ & -18.7 & 9.2 & 43.2 & 15.6 & 3.2 \\
\hline 11,321 & Late Roman & 9234 & Male & $45-49$ & -17.7 & 10.5 & 42.0 & 15.2 & 3.2 \\
\hline 11,322 & Late Roman & 9180 & Female & $18-25$ & -18.5 & 10.7 & 38.3 & 13.8 & 3.2 \\
\hline 11,323 & Late Roman & 7590 & Indet. & $25-30$ & -17.8 & 10.4 & 38.3 & 14.0 & 3.2 \\
\hline 11,324 & Late Roman & 9018 & Indet. & $24-35$ & -18.5 & 10.4 & 34.3 & 12.0 & 3.3 \\
\hline 11,325 & Late Roman & 9258 & Female & $18-22$ & -18.4 & 11.1 & 40.1 & 14.5 & 3.2 \\
\hline 11,326 & Late Roman & 9053 & Indet. & $24-35$ & -18.1 & 9.5 & 38.5 & 13.5 & 3.3 \\
\hline 11,327 & Late Roman & 9037 & Female & $30-40$ & -18.5 & 9.0 & 40.9 & 14.8 & 3.2 \\
\hline 11,328 & Late Roman & 19,226 & Male & $25-30$ & -18.7 & 8.4 & 37.9 & 13.8 & 3.2 \\
\hline 11,329 & Late Roman & 9019 & Male & $24-35$ & -17.7 & 11.4 & 31.9 & 11.2 & 3.3 \\
\hline 11,330 & Late Roman & 2085 & Indet. & $24-35$ & -18.2 & 11.9 & 43.4 & 15.6 & 3.2 \\
\hline 11,331 & Late Roman & 2057 & Female & $24-35$ & -18.1 & 10.2 & 42.5 & 14.8 & 3.3 \\
\hline 11,332 & Late Roman & 2031 & Indet. & $25-40$ & -18.0 & 10.0 & 39.9 & 14.3 & 3.3 \\
\hline 11,334 & Late Roman & 2020 & Male & $35-45$ & -18.7 & 11.7 & 42.3 & 15.0 & 3.3 \\
\hline 11,335 & Late Roman & 2048 & Male & 25-35 & -17.8 & 11.6 & 40.3 & 14.4 & 3.3 \\
\hline 11,337 & Late Roman & 2081 & Male & $25-35$ & -18.3 & 11.1 & 40.2 & 14.5 & 3.2 \\
\hline 11,339 & Late Roman & 2107 & Indet. & $25-35$ & -18.2 & 11.0 & 39.8 & 14.0 & 3.3 \\
\hline 11,340 & Late Roman & 2064-1 & Female & $25-35$ & -18.3 & 11.8 & 40.2 & 14.5 & 3.2 \\
\hline 11,341 & Late Roman & 2009 & Indet. & $18-35$ & -18.2 & 10.5 & 38.5 & 13.2 & 3.4 \\
\hline 11,342 & Late Roman & 2078 & Indet. & $24-35$ & -18.2 & 11.1 & 41.0 & 14.6 & 3.3 \\
\hline 11,343 & Late Roman & 2044-1 & Indet. & $18-33$ & -17.8 & 10.5 & 38.9 & 14.2 & 3.2 \\
\hline 11,344 & Late Roman & 2063-1 & Female & $35-45$ & -18.4 & 12.0 & 40.9 & 14.7 & 3.2 \\
\hline 11,345 & Late Roman & 2052 & Indet. & $25-35$ & -18.5 & 10.5 & 42.8 & 15.6 & 3.2 \\
\hline 11,346 & Late Roman & 2016 & Indet. & $35-45$ & -17.7 & 10.7 & 39.6 & 14.1 & 3.3 \\
\hline 11,347 & Late Roman & $2049-3$ & Female & $35-50$ & -18.7 & 11.5 & 42.3 & 15.4 & 3.2 \\
\hline 11,348 & Late Roman & 2115 & Indet. & $25-35$ & -18.5 & 10.7 & 43.1 & 15.7 & 3.2 \\
\hline 11,349 & Late Roman & 2047 & Indet. & $24-35$ & -17.8 & 10.6 & 38.0 & 13.4 & 3.3 \\
\hline 11,350 & Late Roman & 2147 & Indet. & $18-25$ & -18.3 & 10.5 & 35.8 & 13.2 & 3.2 \\
\hline 11,351 & Late Roman & 2082 & Male & $25-35$ & -18.3 & 11.7 & 42.3 & 15.3 & 3.2 \\
\hline 11,352 & Late Roman & 2125 & Male & $>45$ & -18.2 & 11.6 & 39.2 & 14.1 & 3.2 \\
\hline 11,353 & Late Roman & $2063-2$ & Male & $>45$ & -18.3 & 12.2 & 43.4 & 15.7 & 3.2 \\
\hline 11,354 & Late Roman & $2063-3$ & Indet. & $24-35$ & -18.5 & 11.7 & 40.8 & 14.7 & 3.2 \\
\hline 11,355 & Late Roman & 2074 & Male & $20-30$ & -18.1 & 10.8 & 38.1 & 13.7 & 3.3 \\
\hline 11,356 & Late Roman & 9171 & Male & $20-24$ & -18.3 & 10.9 & 41.1 & 14.8 & 3.2 \\
\hline 11,373 & Medieval (Islamic) & 10,544 & Male & $18-30$ & -18.0 & 12.5 & 41.6 & 15.0 & 3.2 \\
\hline 11,374 & Medieval (Islamic) & 10,534 & Indet. & $24-35$ & -18.0 & 10.6 & 44.1 & 16.0 & 3.2 \\
\hline 11,375 & Medieval (Islamic) & 10,513 & Indet. & $20-30$ & -18.7 & 11.4 & 42.2 & 15.6 & 3.1 \\
\hline 11,376 & Medieval (Islamic) & 10,531 & Indet. & $33-46$ & -18.0 & 11.9 & 42.9 & 15.2 & 3.3 \\
\hline 11,377 & Medieval (Islamic) & 10,507 & Female & $30-34$ & -18.2 & 12.0 & 36.8 & 13.4 & 3.2 \\
\hline 11,378 & Medieval (Islamic) & 10,520 & Male & $33-42$ & -18.1 & 11.9 & 34.9 & 12.8 & 3.2 \\
\hline 11,379 & Medieval (Islamic) & 10,541 & Male & $45-50$ & -18.2 & 12.8 & 42.4 & 15.5 & 3.2 \\
\hline 11,380 & Medieval (Islamic) & 10,537 & Female & $40-45$ & -18.7 & 11.7 & 42.5 & 15.5 & 3.2 \\
\hline 11,382 & Medieval (Islamic) & 10,509 & Male & $40-45$ & -19.1 & 9.2 & 29.4 & 10.6 & 3.3 \\
\hline 11,383 & Medieval (Islamic) & 10,516 & Male & $20-25$ & -18.3 & 10.8 & 26.3 & 9.2 & 3.3 \\
\hline 26,738 & Medieval (Islamic) & $2049-2$ & Indet. & $18-25$ & -18.5 & 11.4 & 43.1 & 16.1 & 3.1 \\
\hline 26,739 & Medieval (Islamic) & 2337 & Male & $45-50$ & -18.4 & 10.8 & 43.0 & 15.9 & 3.2 \\
\hline 26,740 & Medieval (Islamic) & 7482 & Male & $20-24$ & -18.4 & 11.4 & 41.5 & 15.5 & 3.1 \\
\hline 26,741 & Medieval (Islamic) & 7609 & Indet. & $24-35$ & -18.0 & 11.6 & 34.0 & 12.5 & 3.2 \\
\hline
\end{tabular}


a

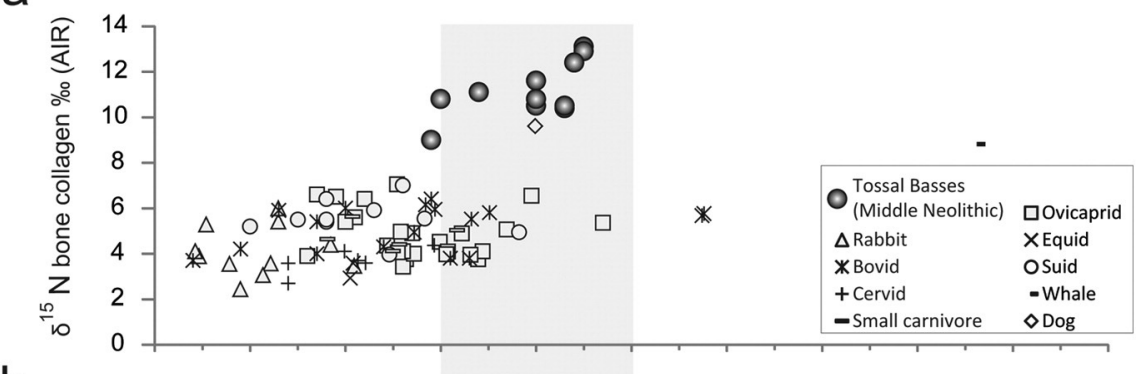

b

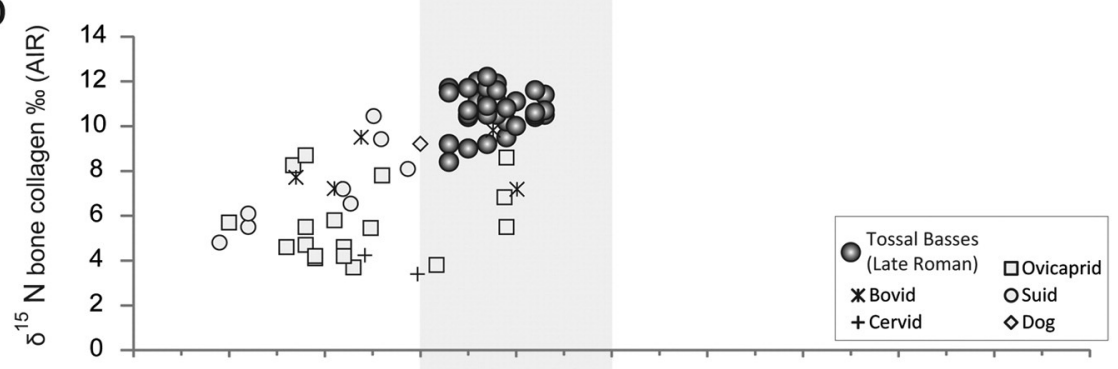

C

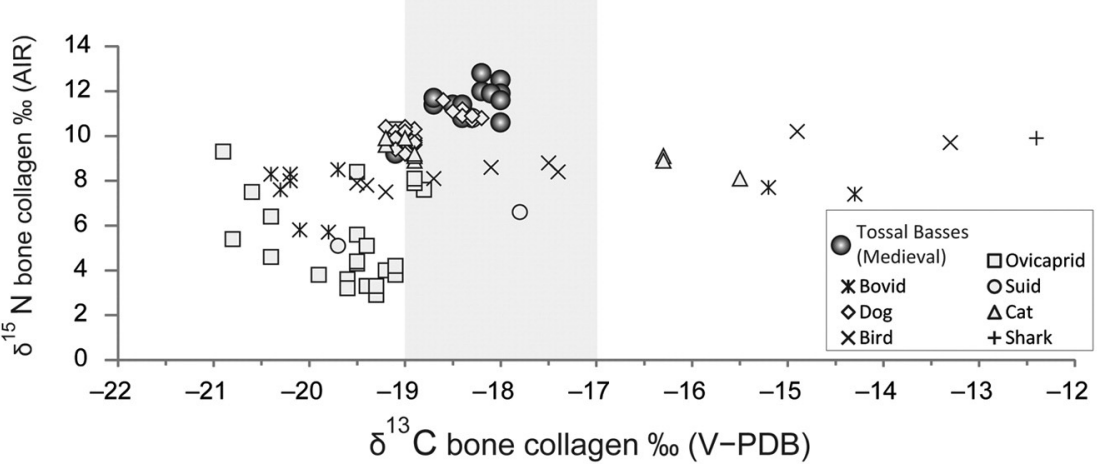

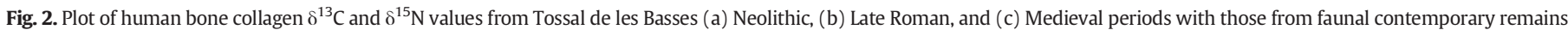
from other sites of the region.

All humans from the Middle Neolithic period $(n=12)$ have $\delta^{13} \mathrm{C}$ and $\delta^{15} \mathrm{~N}$ mean values of $-18.1 \pm 0.6(1 \sigma) \%$ ( $\min :-19.1 \%$, max: $-17.5 \%$ ) and $11.2 \pm 1.2(1 \sigma) \%$ ( $\min : 9.0 \%$, max: $13.1 \%$ ) respectively. Individuals from the Late Roman period $(n=37)$ have $\delta^{13} \mathrm{C}$ and $\delta{ }^{15} \mathrm{~N}$ mean values of $-18.2 \pm 0.3(1 \sigma) \%$ ( $\min :-18.7 \%$, $\max :-17.7 \%$ o) and $10.8 \pm 0.9(1 \sigma) \%$ o (min: $8.4 \%$, max: $12.2 \%$ ) respectively. Finally, humans from the Medieval period show $\delta^{13} \mathrm{C}$ and $\delta^{15} \mathrm{~N}$ mean values of $-18.3 \pm 0.3(1 \sigma) \%$ ( $\min :-19.1 \%$ o, $\max :-18.0 \%$ ) and $11.4 \pm 0.9$

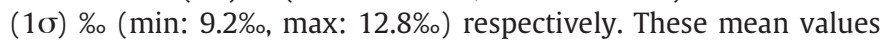
show that all populations from the different periods had an overall similar diet based on terrestrial $C_{3}$ resources. No differences were found among periods when $\delta^{13} \mathrm{C}$ and $\delta^{15} \mathrm{~N}$ values are compared (ANOVA; $P>0.05)$.

The analysis of covariance indicated non-equal adjusted means in the three groups (ANCOVA: $F=3.613 ; P=0.033$ ) and shows that there is a population trend towards higher carbon and nitrogen values suggesting a clear isotopic evidence of the input of some marine protein in the diet of some individuals during the Middle Neolithic $\left(\mathrm{R}^{2}=0.44 ; r=0.664 ; P=0.02\right)$ and perhaps also in the Medieval period $\left(\mathrm{R}^{2}=0.36 ; r=0.601 ; P=0.02\right)$. In the Late Roman period the slight population trend towards higher carbon values does not correlate with an increase in nitrogen isotope values $\left(\mathrm{R}^{2}=0.01 ; r=0.105 ; P=0.53\right)$, probably reflecting the incorporation of small quantities of $C_{4}$ resources to the diet of some individuals. Given that there are no comparable contemporary animal remains from the site, further interpretation of the nitrogen isotope values of the human isotopic signals is however limited.

\subsection{Buccal-microwear pattern}

Buccal-microwear results for the populations analyzed are provided in Table 3 and Fig. 3. Significant statistical differences among groups in microwear pattern were found (ANOVA; $P<0.05$ ). When comparisons are made across the three groups, we found that the buccal-microwear of the Neolithic and Medieval populations is characterized by a high density of small microwear features, indicative of a more abrasive diet than that of Late Roman individuals (Table 3 and Fig. 3a). Moreover, buccal-microwear for the Neolithic individuals is comparable to the Medieval sample. No significant differences (Tukey's HSD; $P>0.05$ ) were found in scratch density (NT) and length (XT) signatures between these populations. However, Late Roman individuals were found to have a significantly lower number of microwear features larger in size (Tukey's HSD; $P<0.001$ ) compared to Neolithic and Medieval human groups (Table 3 and Fig. $3 b$ ).

\subsection{Isotope and microwear comparison}

Analysis of temporal variation in stable isotope ratios from bone collagen $\left(\delta^{13} \mathrm{C}\right.$ and $\left.\delta^{15} \mathrm{~N}\right)$ and buccal-microwear (NT and XT) patterns in Tossal de les Basses reveals no significant trends over time (RMA regressions $P>0.05$ ). However, we found significant correlation coefficients (Spearman's Rho 0.544; $P=0.03 ; n=16$ ) between $\delta^{15} \mathrm{~N}$ and scratch density (NT) for individuals by sites that showed both type of dietary signals. This data indicate that microwear features tend to increase 
Table 3

Descriptive and statistical summary of buccal-microwear for the groups analyzed.

\begin{tabular}{|c|c|c|c|}
\hline \multicolumn{4}{|c|}{ A. Microwear measurements } \\
\hline & Mean & SD & SE \\
\hline \multicolumn{4}{|l|}{ Microwear-density (NT) } \\
\hline Middle Neolithic & 339.875 & 173.372 & 61.296 \\
\hline Late Roman & 104.539 & 46.174 & 9.055 \\
\hline Medieval (Islamic) & 257.167 & 65.974 & 26.934 \\
\hline \multicolumn{4}{|l|}{ Microwear-length (XT) } \\
\hline Middle Neolithic & 62.824 & 19.066 & 6.741 \\
\hline Late Roman & 96.862 & 20.085 & 3.939 \\
\hline Medieval (Islamic) & 71.527 & 4.111 & 1.678 \\
\hline \multicolumn{4}{|l|}{ B. Individual ANOVAS } \\
\hline df & Mean square & $\mathrm{F}$ & $P$ \\
\hline \multicolumn{4}{|l|}{ Microwear-density (NT) } \\
\hline Effect $\quad 2$ & 1487.738 & 23.409 & $0.000^{*}$ \\
\hline Error & 63.555 & & \\
\hline \multicolumn{4}{|l|}{ Microwear-length (XT) } \\
\hline Effect 2 & 1142.582 & 13.884 & $0.000^{*}$ \\
\hline Error & 82.293 & & \\
\hline \multicolumn{4}{|c|}{ C. Multiple comparisons test (Tukey's HSD) } \\
\hline \multirow[t]{4}{*}{ Microwear-density (NT) } & & Neolithic & Late-Roman \\
\hline & Middle Neolithic & - & \\
\hline & Late Roman & 18.389* & - \\
\hline & Medieval (Islamic) & 0.729 & $17.660^{*}$ \\
\hline \multicolumn{4}{|l|}{ Microwear-length (XT) } \\
\hline & Middle Neolithic & - & \\
\hline & Late Roman & $16.413^{*}$ & - \\
\hline & Medieval (Islamic) & 1.375 & $15.038^{*}$ \\
\hline
\end{tabular}

Significant differences at $P<0.05\left(^{*}\right)$. Microwear length in micrometers $(\mu \mathrm{m})$.

among groups with higher $\delta^{15} \mathrm{~N}$ values and suggests that marine-based gritty food resources were used in the Neolithic and Medieval populations in much greater frequency than in the Late Roman period individuals.

\section{Discussion and conclusions}

Isotopic data from bone collagen and microwear patterns on buccal tooth enamel surfaces are rarely combined to examine diet in past human populations (García-González et al., 2015). Our findings show that both methods bring complementary data together, providing a novel way to explore dietary history among populations. The nature of the information obtained from both techniques concerns types of foods eaten and their properties. They show a complex data set that illustrates diversity in both dietary and diachronic trends in food consumption (most likely comprising both terrestrial and marine resources) and processing methods for the populations at Tossal de les Basses site.

The carbon and nitrogen stable isotope ratio results from Tossal de les Basses have shown that the diet from the three time periods is based on terrestrial $C_{3}$ resources. However, they also suggest some differences between them concerning marine resource consumption. Since there were no faunal remains available for analysis at the site, and in order to get a more precise picture of the previously suggested human population trends, we have compared the human values from our site with those of contemporary faunal remains from Eastern Iberia and Ibiza published (see Fig. 1). We found that for all three time periods the humans are overall higher in $\delta^{15} \mathrm{~N}$ than the terrestrial fauna (Fig. 2). The highest difference between human and terrestrial herbivore and omnivore $\delta^{15} \mathrm{~N}$ values occurs at the Middle Neolithic phase of Tossal de les Basses and is $6.6 \%$ for herbivores and of $5.3 \%$ o for omnivores (Fig. 2a). This high $\delta^{15} \mathrm{~N}$ difference, together with an increase of the human $\delta^{13} \mathrm{C}$ values of $1.5 \%$ o compared to terrestrial herbivores and of
$1.6 \%$ compared to omnivores, supports that this population was consuming marine resources on a regular basis (enough to be seen in adult bone collagen). In the case of the Roman population (Fig. 2b), the $\delta{ }^{15} \mathrm{~N}$ mean difference with that of herbivores (4.7\%) and omnivores $(3.3 \%$ ) is smaller and suggests no isotopic evidence of marine protein consumption. Perhaps medieval people were also consuming some marine resources, but only sporadically, since their isotope values show no clear evidence of this when compared to contemporary fauna (Fig. 2c). In fact, the medieval population shows a similar trophic-chain pattern to the Roman one, having a $\delta^{15} \mathrm{~N}$ mean difference with herbivores of $4.8 \%$ and with omnivores of $1.6 \%$. Thus, another type of dietary explanation should be considered to explain the human trend increase in both carbon and nitrogen values, perhaps the consumption of freshwater and $C_{4}$ resources together (Marin and Waines, 1994; Villegas Becerril, 2001) (consumption of freshwater resources could increase $\delta^{15} \mathrm{~N}$, while consumption of $\mathrm{C}_{4}$ resources should increase $\delta^{13} \mathrm{C}$ ). Moreover, diets low in carbohydrate and high in protein lead to minimal caries and elevated calculus rates (Keenleyside, 2008). The frequency of permanent teeth affected by caries (5.4\%) and medium-level of dental calculus (12\%) in the Medieval group from the Tossal de les Basses recovered individuals (Laguillo et al., 2009) suggest that animal products made a relative high contribution to diet (Bonsall and Pickard, 2015). Unfortunately, there are no available data from the Neolithic and Roman populations regarding oral disease.

The Tossal de les Basses Neolithic population isotopic values $\left(\delta^{13} \mathrm{C}\right.$ mean $=-18.1 \pm 0.6[1 \sigma], \delta^{15} \mathrm{~N}$ mean $\left.=11.2 \% \circ \pm 1.2[1 \sigma]\right)$ can be compared to those of the Mesolithic adult individuals of El Collado (GarcíaGuixé et al., 2006), Casa Corona (Fernández-López de Pablo et al., 2013), Santa Maira, Penya del Comptador and Cingle del Mas Nou (SalazarGarcía et al., 2014a) combined together $\left(n=19 ; \quad \delta^{13} \mathrm{C}\right.$ mean $=-18.4 \pm 0.5[1 \sigma] \%$, $\delta^{15} \mathrm{~N}$ mean $\left.=9.3 \% \circ \pm 1.3[1 \sigma]\right)$, as well as to those of the adult Neolithic-Chalcolithic individuals of Costamar (Salazar-García, 2009), La Vital (Salazar-García, 2011a), Cova Pastora, Avenc Dos Forats (McClure et al., 2011), Coveta del Frare (García-Borja et al., 2013), Cova Diablets (Salazar-García, 2014), Ibiza (Fuller et al., 2010; Nehlich et al., 2012), Bòbila Madurell and Can Gambús (Fontanals-Coll et al., 2015) added together $\left(n=108 ; \delta^{13} \mathrm{C}\right.$ mean $=-19.4 \pm 0.5[1 \sigma] \%$, $\delta^{15} \mathrm{~N}$ mean $\left.=9.4 \% \circ \pm 1.2[1 \sigma]\right)$. The isotopic values from the Tossal de les Basses Neolithic population are more similar to that of the Mesolithic period than the Neolithic period in the region, especially in the case of $\delta^{13} \mathrm{C}$. This is interesting, as in a region with no evidence of $\mathrm{C}_{4}$ resources during the Mesolithic and Neolithic (Salazar-García, 2012), this suggests a similar marine protein consumption as reported for the Mesolithic population in the region, but different than the exclusive terrestrial values seen for the Neolithic-Chalcolithic sites studied so far. This is of importance, because so far there is no clear marine isotopic signature seen at any Mediterranean Neolithic population, not even at sites surrounded by sea like those from the island of Malta (Richards et al., 2001). The combination of DNA and isotopic analysis from a site in Central Germany has suggested the presence of different mitochondrial lineages linked to diverse dietary practices during the Neolithic period (Bollongino et al., 2013), opening the possibility to further explore this possibility for Neolithic dietary patterns observed elsewhere in Europe.

On the other hand, the Roman population of Tossal de les Basses does cluster quite well with human adult individuals from the Late Roman-Byzantine site of Ibiza (Fuller et al., 2010), as well as with the Punic sites of Can Marines, Ses Païsses de Cala d'Hort and Via Romana 47-Puig des Molins in Ibiza (Fuller et al., 2010; Salazar-García, 2011b). All these populations, which are the only ones from Antiquity and Late Antiquity whose isotope data have been published in the region so far, have a combined $(n=143) \delta^{13} \mathrm{C}$ mean value of $-18.6 \pm 0.4[1 \sigma] \%$ and a $\delta^{15} \mathrm{~N}$ mean value of $11.5 \%$ o $\pm 1.0[1 \sigma]$ with ranges of $-19.7 \%$ 。 to $-17.7 \%$ and $8.3 \%$ o to $13.3 \%$ respectively. These very similar and tightly clustered values suggest that the ancient Western Mediterranean commercial network and social mobility was probably responsible for 
a
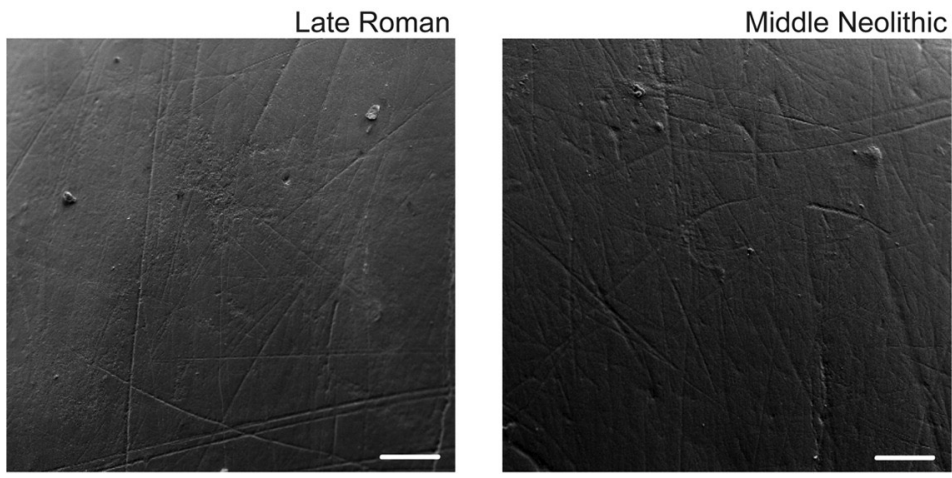

b

Dietary abrasiveness

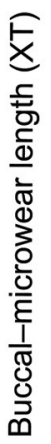

110
100
90
80
70
60
50

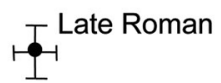

\section{Medieval}

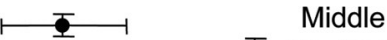

Neolithic

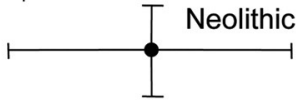

50

150

250

350

450

Buccal-microwear density (NT)

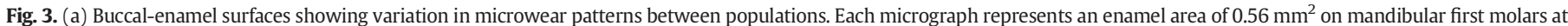

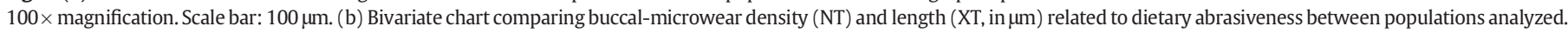
Error bars denote $\pm 1 \mathrm{SD}$

people from different contemporary cultures (Punics-Romans, RomansByzantine) consuming similar types of foods and having similar dietary patterns (or at least to the extent that their isotope values were similar).

This apparent homogeneity in Western Mediterranean ancient populations disappears when looking at the Medieval values from the region (Alexander et al., 2015; Salazar-García et al., 2014b), including those recorded from Tossal de les Basses. Together $(n=114)$ they have a $\delta^{13} \mathrm{C}$ mean value of $-17.1 \pm 1.2[1 \sigma] \%$ and a $\delta^{15} \mathrm{~N}$ mean value of $11.2 \%$ o $\pm 1.0[1 \sigma]$ with ranges of $-19.4 \%$ o to $-13.1 \%$ ond $8.5 \%$ o to $13.0 \%$ respectively. We can see how during Medieval times, the range of $\delta^{13} \mathrm{C}$ values (6.2\%) is much higher than during the previous Antiquity and Late Antiquity times (2.0\%). This might suggest two main things. For one, it seems clear that $\mathrm{C}_{4}$ resources were having overall a greater impact among Medieval than ancient population diets, since the wider $\delta^{13} \mathrm{C}$ range is not associated to an increase of $\delta^{15} \mathrm{~N}$. This difference could also show that dietary patterns were more varied during medieval times, perhaps due to an increase in religious differences between individuals or due to a diminishment of economic networking and social mobility (Bazzana, 1998; Guichard, 2001).

The microwear analysis conducted as part of this study focused on buccal tooth surfaces and suggests that changes in dietary abrasiveness were most likely related to food acquisition and processing methods, rather than general dietary regimes among populations examined, since high abraded enamel surfaces can be caused by factors other than dietary-related ones (Romero and De Juan, 2007; Romero et al., 2012). However, another reason for the significant changes in dietary textures is probably due to the type of meat and agricultural products consumed.

The highly abraded microwear patterns shown by the Neolithic group resemble those observed in the Medieval population and differ from the Late Roman period individuals. These findings clearly indicate that the Neolithic and Medieval diets were composed of coarsely processed foods, which include a relatively large amount of exogenous grits that could explain the extensive microwear patterns. The presence of a high number of relatively short scratches supports the suggestion that these populations ate hard and brittle foods that required a significant amount of compression during mastication (Romero and De Juan, 2007). Contrary to this, a radical reduction in abrasive particle associated with changes in both food content and preparation methods throughout Roman culture is recorded.

The effect of specific abrasive agents on buccal enamel surfaces is difficult to characterize. However, plant silica phytoliths mainly forming small microwear features remodeling microwear patterns, and exogenous grit contaminants causing dramatic micro-indentation enamel damage, even with modest biomechanical loadings, affect turn-over rates (Gügel et al., 2001; Romero et al., 2012).

Botanical and zoological evidence suggests that between the Neolithic and Medieval periods there was no dramatic change in the plant and terrestrial animal species that were exploited in Eastern Iberia (Carrión-Marco, 2015; Martin, 2003). Accordingly, these food resources should not be responsible for the observed group differences in the proportions of microwear features. However, during the Middle Neolithic period at Tossal de les Basses there was a heavy reliance on hunting (e.g. red deer and horse), as well as on the gathering of wild plants and marine resources such as mollusks (Rosser, 2010, 2012; Pascual Benito, 2014). In turn, it is likely that the human groups during the Neolithic lived an increasingly sedentary life with a reliance on domesticated plant species (e.g. Hordeum vulgare and Triticum aestivum) but a continuance in the hunting, fishing and gathering (Rosser, 2012) as the isotopic signal obtained have indicated. In contrast, during the 
Roman period there was a reliance mainly on terrestrial resources (Martin and Rosser, 1993; Carrión-Marco, 2015). However, the observed change in dietary texture may also be due to technological reasons. The switch from stone mortars to wooden mortars for cereal processing in Roman times (Carrión-Marco, 2015) could introduce little or no grit contaminants into the food and therefore decrease the dietary abrasiveness of the grain ingested (Hogue and Melsheimer, 2008).

Early experimental in vivo microwear analysis (Romero et al., 2012) show that stone-ground flour processed with a quartzite mortar or roasted meat resources introduces copious amounts of grit into the diet, leading to an increase in microwear features. Thus, different sized contaminants from stone-ground foods and marine or terrestrial meat resources could explain the variability of microwear patterns found among populations (Lalueza et al., 1996; Romero et al., 2013). In this context, the microwear evidence on ancient populations from Eastern Iberia have found further indicates that horticultural dependency is usually associated with a more refined diet and decrease of microwear features (Romero and De Juan, 2007). Specifically, microwear features from Bronze Age economies (Romero and De Juan, 2007, Polo-Cerdá et al., 2007) resemble those obtained in the Late Roman population here studied. Instead, the microwear patterns found in other Neolithic and Chalcolithic groups were more similar to that displayed for the Neolithic individuals, probably due to gritty and less refined diets (Romero and De Juan, 2004, 2007, 2012). Moreover, archaeological data show that during historical periods, both the agricultural product support and the presence of salting factories connecting with the fishing trade, were the mainly developed economic activities at Tossal de les Basses site (Figueras Pacheco, 1959). The extent of buccal-microwear in the Medieval cultural context could indicate high and regular consumption of grain that was heavily contaminated with abrasives from millstones and fish, eaten dried on open racks, significantly contributed to enamel indentation processes (Romero et al., 2012).

In summary, combining both isotope and microwear data, we have found that although terrestrial $C_{3}$ resources are the predominant part of the diet for all three periods, some slight differences can be observed between time periods at the same site and geographical location. Marine protein input in the diet was scarce in the Medieval and Roman period compared to the Neolithic. Both the Middle Neolithic and Medieval diets were probably less processed, resulting in large amount of food grits that had different physical and mechanical properties and thus could have masked changes in diet. By contrast, the Roman diet appears to be softer and contaminated more with grit-laden foods with smaller and more uniform size particles. Thereby, our findings suggest that habitat resource exploitation plays a less significant role in dietary patterns than do cultural factors affecting food technical processing methods and types of food chosen. Furthermore, our study shows the advantages of a combined approach to establish the dietary adaptations of human populations.

\section{Acknowledgments}

We thank Pablo Rosser (Ajuntament d'Alacant) for granting the access to the remains studied and its sampling. Part of this research was part of DCSG's PhD, funded by the Max Planck Society (Prof. Hublin) and the Spanish Ministerio de Ciencia y Tecnología through a FPU predoctoral scholarship (ref. AP2005-1509). The development of this work was also supported by the BBVA Foundation (I Ayudas a Investigadores, Innovadores y Creadores), the Generalitat Valenciana (VALi + d APOSTD/2014/123), Aduna Proexa SL (Grant no. 1-06I), and the European Union (FP7/2007-2013-MSCA-COFUND, no. 245743 via a Braudel-IFER-FMSH in collaboration with the LAMPEA lab at the Université d'Aix-Marseille). All authors would like to thank the helpful comments from two anonymous reviewers.

\section{References}

Alexander, M.M., Gerrard, C.M., Gutiérrez, A., Millard, A.R., 2015. Diet, society, and economy in Late Medieval Spain: stable isotope evidence from Muslims and Christians from Gandía, Valencia. Am. J. Phys. Anthropol. 156, 263-273.

Aranegui, C., Mohen, J.P., Rouillard, P., 1998. Los Iberos. Príncipes de Occidente. Fundación la Caixa, Barcelona.

Arce Martínez, J.J., Montenegro, A., Mangas, J., Sayas, J.J., Roldán, J.M., Blázquez, J.M., Iglesias, L.G., Teja, R., 2007. Historia de España antigua: Hispania romana. Cátedra, Barcelona.

Badal, E., Martí, B., Pérez-Ripoll, M., 2012. From agricultural to pastoral use: changes in neolithic landscape at Cova de l'Or (Alicante, Spain). In: Badal, E., Carrión-Marco, Y., Macías, M., Ntinou, M. (Eds.), Wood and Charcoal. Evidence for human and natural history. Sagvntvm 13, pp. 75-84.

Bazzana, A., 1998. Villages et terroirs andalous: Quelques aspects du peuplement médiéval et de l'exploitation agraire dans al-Andalus. Ruralia 2, 140-151.

Belenguer, E., 2007. Història de la Corona d'Aragó. Edicions 62, Barcelona.

Bernabeu, J., Orozco, T., 2014. Mediterranean Iberia in the 4th and 3rd milennia. In: Almagro, M. (Ed.), Iberia. Protohistory of the Far West of Europe. From Neolithic to Roman Conquest. Universidad de Burgos-Fundación Atapuertca, Burgos, pp. 19-41.

Bollongino, R., Nehlich, O., Richards, M.P., Orschiedt, J., Thomas, M.G., Sell, C., Fajkošová, Z., Powell, A., Burger, J., 2013. 2000 Years of Parallel Societies in Stone Age Central Europe. Science Express.

Bonsall, A.L., Pickard, C., 2015. Stable isotope and dental pathology evidence for diet in late Roman Winchester, England. J. Archaeol. Sci. Rep. 2, 128-140.

Buikstra, J.E., Ubelaker, D.H., 1994. Standards for Data Collection From Human Skeletal Remains. Arkansas Archaeological Survey Research Series No. 44Arkansas Archeological Survey, Fayetteville.

Carrión-Marco, Y, 2015. Tossal de les Basses, Alicante. In: Carrión, JS. (Ed.) Cinco millones de años de cambio florístico y vegetal en la Península Ibérica e Islas Baleares. Universidad de Murcia y Fundación Séneca, Murcia, pp. 678-679.

Chisholm, B.S., Nelson, D.E., Schwarcz, H.P., 1982. Stable carbon isotope ratios as a measure of marine versus terrestrial protein in ancient diets. Science 216, 1131-1132.

Conover, W.J., Iman, R.L., 1981. Rank transformations as a bridge between parametric and nonparametric statistics. Am. Stat. 35, 124-129.

De Niro, M.J., 1985. Postmortem preservation and alteration of in vivo bone collagen isotope ratios in relation to palaeodietary reconstruction. Nature 317, 806-809.

Fahy, G., Richards, M., Riedel, J., Hublin, J.-J., Boesch, C., 2013. Stable isotope evidence of meat eating and hunting specialization in adult male chimpanzees. Proc. Natl. Acad. Sci. U. S. A. 110, 5829-5833.

Fernández-López de Pablo, J., Salazar-García, D.C., Subirà, M.E., Roca-Togores, C., Gómez Puche, M., Richards, M.P., Esquembre Bebiá, M.A., 2013. Late Mesolithic burials of Casa Corona (Villena, Spain): direct radiocarbon and paleodietary evidence of last forager populations in Eastern Iberia. J. Archaeol. Sci. 40, 671-680.

Figueras Pacheco, F., 1959. Dos mil años atrás. Las ciudades, el puerto y la necrópolis de la Albufereta, Alicante. Instituto de Estudios Alicantinos, Alicante.

Fontanals-Coll, M., Subirà, M.E., Díaz-Zorita Bonilla, M., Duboscq, S., Gibaja, J.F., 2015. Investigating palaeodietary and social differences between two differentiated sectors of a Neolithic community, La Bòbila Madurell-Can Gambús (north-east Iberian Peninsula). J. Archaeol. Sci. Rep. 3, 160-170.

Fuller, B.T., Márquez-Grant, N., Richards, M.P., 2010. Investigation of diachronic dietary patterns on the Islands of Ibiza and Formentera, Spain: evidence from carbon and nitrogen stable isotope ratio analysis. Am. J. Phys. Anthropol. 143, 512-522.

Furió, A., 2001. Història del País Valencià. Tres i Quatre, València.

Galbany, J., Martínez, L.M., López-Amor, H.M., Espurz, V., Hiraldo, O., Romero, A., De Juan, A., Pérez-Pérez, A., 2005. Error rates in buccal-dental microwear quantification using Scanning Electron Microscopy. Scanning 27, 23-29.

Galbany, J., Estebaranz, F., Martínez, L.M., Romero, A., De Juan, J., Turbón, D., Pérez-Pérez, A., 2006. Comparative analysis of dental enamel polyvinylsiloxane impression and polyurethane casting methods for SEM research. Microsc. Res. Tech. 69, 246-252.

García-Borja, P., Pérez Fernández, A., Biosca Cirujeda, V., Ribera i Gomes, A., Salazar-García, D.C., 2013. Los restos humanos de la Coveta del Frare (La Font de la Figuera, València). In: García Borja, P., Revert Francés, E., Ribera i Gomes, A., Biosca Cirujeda, V. (Eds.), El Naiximent d'un Poble. Història i Arqueologia de la Font de la Figuera. Ajuntament de la Font de la Figuera, València, pp. 47-60.

García-González, R., Carretero, J.M., Richards, M.P., Rodríguez, L., Quam, R., 2015. Dietary inferences through dental microwear and isotope analyses of the Lower Magdalenian individual from El Mirón Cave (Cantabria, Spain). J. Archaeol. Sci. 60, 28-38.

García-Guixé, E., Subirà, M.E., Richards, M.P., 2006. Paleodiets of humans and fauna from the Spanish Mesolithic site of El Collado. Curr. Anthropol. 47, 549-556.

García-Guixé, E., Martínez-Moreno, J., Mora, R., Núñez, M., Richards, M.P., 2009. Stable isotope analysis of human and animal remains from the Late Upper Palaeolithic site of Balma Guilanyà, southeastern Pre-Pyrenees, Spain. J. Archaeol. Sci. 36, 1018-1026.

García-Moreno, L.A., 1989. Historia de España Visigoda. Cátedra, Madrid.

González-Ferrín, E., 2007. Historia General de Al-Ándalus. Almuzara, Córdoba.

Gügel, I.L., Grupe, G., Kunzelmann, K.H., 2001. Simulation of dental microwear: characteristic traces by opal phytoliths give clues to ancient human dietary behavior. Am. J. Phys. Anthropol. 114, 124-138.

Guichard, P., 2001. Al-Andalus frente a la conquista cristiana. Los musulmanes de Valencia (siglos XI-XIII). Universitat de València, València.

Hedges, R.E.M., Reynard, L.M., 2007. Nitrogen isotopes and the trophic level of humans in archaeology. J. Archaeol. Sci. 34, 1240-1251.

Hedges, R.E.M., Clement, J.G., Thomas, C.D.L., O'Connell, T.C., 2007. Collagen turnover in the adult femoral mid-shaft: modeled from anthropogenic radiocarbon tracer measurements. Am. J. Phys. Anthropol. 133, 808-816. 
Hernández, L., Hernández, M., 2004. La Edad del Bronce en tierras Valencianas y zonas limítrofes. Ajuntament de Villena e Instituto alicantino de cultura Juan Gil Albert, Villena.

Hogue, S.H., Melsheimer, R., 2008. Integrating dental microwear and isotopic analyses to understand dietary change in East-Central Mississippi. J. Archaeol. Sci. 35, 228-238.

Katzenberg, M.A., 2012. The ecological approach: understanding past diet and the relationship between diet and disease. In: Grauer, A.L. (Ed.), A Companion to Paleopathology. Blackwell Publishing Ltd., Oxford, pp. 97-113.

Keenleyside, A., 2008. Dental pathology and diet at Apollonia, a Greek colony on the Black Sea. Int. J. Osteoarchaeol. 18, 262-279.

Knapp, B., Van Dommelen, P., 2015. The Cambridge Prehistory of the Bronze and Iron age Mediterranean. Cambridge University Press, Cambridge.

Laguillo, O., Núñez, A., Jordana, X., Rosser, P., Malgosa, A., 2009. Caracterización bioantropológica de una población islámica en Alicante: los enterramientos de época alto-medieval del Tossal de les Basses. Rev. Esp. Antropol. Fís. 30, 51-74.

Lalueza, C., Pérez-Pérez, A., Turbón, D., 1996. Dietary inferences through buccal microwear analysis of Middle and Upper Pleistocene human fossils. Am. J. Phys. Anthropol. 100, 367-387.

Larsen, C.S., 1997. Bioarchaeology: Interpreting Behavior From the Human Skeleton. Cambridge University Press, Cambridge.

Lee-Thorp, J.A., 2008. On isotopes and old bones. Archaeometry 50, 925-950.

Lillie, M.C., Richards, M.P., 2000. Stable isotope analysis and dental evidence of diet at the Mesolithic-Neolithic transition in Ukraine. J. Archaeol. Sci. 27, 965-972.

Marin, M., Waines, D., 1994. La alimentación en las culturas islámicas. Agencia Española de Cooperación Internacional, Madrid.

Martí, B., Juan-Cabanilles, J., 2014. The first Mediterranean Neolithic farmers (VI-V milennia BC). In: Almagro, M. (Ed.), Iberia. Protohistory of the Far West of Europe. From Neolithic to Roman Conquest. Universidad de Burgos-Fundación Atapuerca, Burgos, pp. 19-41.

Martí, B., Aura, E., Juan-Cabanilles, J., García-Puchol, O., Fernández, J., 2009. El mesolítico geométrico en el País Valenciano. In: Utrilla Miranda, P., Montes Ramírez, L. (Eds.), El Mesolítico geométrico en la península Ibérica. Monografías Arqueológicas 44, pp. 205-258.

Martin, C., 2003. La evolución del paleopaisaje en el poblamiento antiguo de Alicante: el yacimiento ibérico del Tossal de les Basses. In: Rosser Limiñana, P., Elayi, J., Pérez Burgos, J.M. (Eds.), El Cerro de las Balsas y el Chinchorro: una aproximación arqueológica del Poblamiento Prehistórico e Ibérico de la Albufereta de AlicanteMonográfico del Patrimonio Cultural de Alicante, $n^{\circ} 2$. Ayuntamiento de Alicante, Alicante, pp. 33-56.

Martin, C., Rosser, P., 1993. Arqueología del paisaje en la ciudad y término municipal de Alicante: avance de un estudio interdisciplinar. IV Congreso de Arqueología Medieval Española: sociedades en transición. Diputación Provincial de Alicante, Alicante, pp. 663-669.

McClure, S., García-Puchol, O., Roca, C., Culleton, B., Kennett, D., 2011. Osteological and paleodietary investigation of burials from Cova la Pastora, Alicante, Spain. J. Archaeol. Sci. 38, 420-428.

Minagawa, M., Wada, E., 1984. Stepwise enrichment of ${ }^{15} \mathrm{~N}$ along food chains: further evidence and the relation between ${ }^{15} \mathrm{~N}$ and animal age. Geochim. Cosmochim. Acta 48, 1135-1140.

Morales, J.I., Oms, X., 2012. Las últimas evidencias mesolíticas del NE peninsular y el vacío pre-neolítico. Rubricatum 5, 35-41.

Müldner, G., 2013. Stable isotopes and diet: their contribution to Romano-British research. Antiquity 87, 137-149.

Murail, P., Bruzek, J., Houët, F., Cunha, E., 2005. DSP: a tool for probabilistic sex diagnosis using worldwide variability in hip-bone measurement. Bull. Mém. Soc. Anthropol. Paris 3-4, 167-176.

Nehlich, O., Fuller, B.T., Márquez-Grant, N., M.P., Richards, 2012. Investigation of diachronic dietary patterns on the islands of Ibiza and Formentera, Spain: Evidence from sulfur stable isotope ratio analysis. Am. J. Phys. Anthropol. 149, 115-124.

Pascual Benito, J.L., 2014. El consumo de moluscos marinos durante el Neolítico antiguo en la región central del Mediterráneo peninsular. Archaeofauna 23, 207-222.

Pérez Jordà, G., Peña Chocarro, L., 2013. Agricultural production between the 6th and the 3rd millenium cal BC in the central part of the valencia region (Spain). In: Groot, M., Lentjes, D., Zeiler, J. (Eds.), Barely Surviving or More Than Enough? The Environmental Archaeology of Subsistence, Specialisation and Surplus Food Production. Sidestone Press, Leiden, pp. 81-100.

Pérez-Pérez, A., Lalueza, C., Turbón, D., 1994. Intraindividual and intragroup variability of buccal tooth striation pattern. Am. J. Phys. Anthropol. 94, 175-187.

Polo-Cerdá, M., Romero, A., Casabó, J., De Juan, J., 2007. The Bronze Age burials from Cova Dels Blaus (Vall d'Uixó, Castelló, Spain): an approach to palaeodietary reconstruction through dental pathology, occlusal wear and buccal microwear patterns. J. Comp. Hum. Biol. 58, 297-307.

Reitsema, L.J., 2013. Beyond diet reconstruction: stable isotope application to human physiology, health, and nutrition. Am. J. Hum. Biol. 25, 445-456.

Richards, M.P., Hedges, R.E.M., 1999. Stable isotope evidence for similarities in the types of marine foods used by Late Mesolithic humans at sites along the Atlantic Coast of Europe. J. Archaeol. Sci. 26, 717-722.

Richards, M.P., Montgomery, J., 2012. Isotope analysis and paleopathology: a short review and future developments. In: Buikstra, J., Roberts, C. (Eds.), The Global History of Paleopathology: Pioneers and Prospects. Oxford University Press, Oxford, pp. 718-731.

Richards, M.P., Hedges, R.E.M., Walton, I., Stoddart, S., Maloe, C., 2001. Neolithic diet at the Brochtorff Circle, Malta. Eur. J. Archaeol. 4, 253-262.

Romero, A., De Juan, J., 2004. Patrón bucal de microestriación dental como indicador de dieta en la Cova de San Martí (Agost, Alicante). In: Torregrosa, P., López, E., Jover Maestre, F.J. (Eds.), La Cova Sant Martí (Agost, Alicante). Diputación Provincial de Alicante, Alicante, pp. 99-104.
Romero, A., De Juan, J., 2007. Intra-and interpopulation human buccal tooth surface microwear analysis: inferences about diet and formation processes. Anthopologie $45,61-70$.

Romero, A., De Juan, J., 2012. SEM, teeth and palaeoanthropology: the secret of ancient human diets. In: Schatten, H. (Ed.), Scanning Electron Microscopy for the Life Sciences. Cambridge University Press, Cambridge, pp. 236-256.

Romero, A., Galbany, J., De Juan, J., Pérez-Pérez, A., 2012. Short and long-term in vivo human buccal dental-microwear turnover. Am. J. Phys. Anthropol. 148, 467-472.

Romero, A., Ramírez-Rozzi, F.V., De Juan, J., Pérez-Pérez, A., 2013. Diet-related buccal dental microwear patterns in Central African Pygmy foragers and Bantu-speaking farmer and pastoralist populations. PLoS One 19, e84804.

Rosser, P., 2010. Enterramientos neolíticos y creencias en el Tossal de les Basses: primeros datos. In: Pérez, A., Soler, B. (Eds.), Restes de vida, restes de mort. Museu de Prehistòria de Valencia, València, pp. 183-190.

Rosser, P., 2012. El agua en el origen de la ciudad de Alicante. Una visión históricoarqueológica desde la Prehistoria hasta la época moderna. Ayuntamiento de Alicante, Alicante.

Rosser, P., Fuentes, C., 2007. Tossal de les Basses. Seis mil años de historia de Alicante. Patronato Municipal de Cultura. Ayuntamiento de Alicante.

Ruiz, A., Molinos, M., 1993. Los Iberos. Análisis arqueológico de un proceso histórico. Crítica, Barcelona.

Salazar-García, D.C., 2012. Isótopos, dieta y movilidad en el País Valenciano. Aplicación a restos humanos del Paleolítico medio al Neolítico final. Universitat de València, València (Doctoral Thesis).

Salazar-García, D.C., 2009. Estudio de la dieta en la población neolítica de Costamar. Resultados preliminares de análisis de isótopos estables de carbono y nitrógeno. In: Flors Ureña, E. (Ed.), Torre la Sal (Ribera de Cabanes, Castellón). Evolución del paisaje antrópico desde la prehistoria hasta el medioevo. Servicio de Investigaciones Arqueológicas y Prehistóricas. Diputación de Castellón, Castellón, pp. 411-418.

Salazar-García, D.C., 2011a. Aproximación a la dieta de la población calcolítica de La Vital a través del análisis de isótopos estables del carbono y del nitrógeno sobre restos óseos. In: Perez Jordá, G., Bernabeu Aubán, J., Carrión-Marco, Y., García-Puchol, O., Molina Balaguer, LL, Gómez Puche, M. (Eds.), La Vital (Gandia, Valencia). Vida y muerte en la desembocadura del Serpis durante el III y el I milenio a.C. València. Museu de Prehistòria de València-Diputación de València, València, pp. 139-143.

Salazar-García, D.C., 2011b. Patrón de dieta en la población púnica de Can Marines (Ibiza) a través del análisis de isótopos estables ( $\mathrm{C}$ y N) en colágeno óseo. Saguntum 43, 95-102.

Salazar-García, D.C., 2014. Estudi de la dieta en la població de Cova dels Diablets mitjançant anàlisi d'isòtops estables del carboni i del nitrogen en col·làgen ossi. Resultats preliminars. In: Aguilella Arzo, G., Roman in Monroig, D., García Borja, P. (Eds.), La Cova dels Diablets (Alcalà de Xivert, Castelló). Prehistòria a la Serra d'Irta. Diputació de Castelló, Castellón, pp. 67-78.

Salazar-García, D.C., Vives-Ferrándiz, J., Fuller, B., Richards, M.P., 2010. Alimentación estimada de la población del Castellet de Bernabé (ss. V-III a.C.) mediante el uso de ratios de isótopos estables de C y N. Saguntum 9, 313-322.

Salazar-García, D.C., Power, R.C., Sanchis-Serra, A., Villaverde, V., Walker, M.J., Henry, A.G 2013a. Neanderthal diets in central and southeastern Mediterranean Iberia. Quat. Int 318, 3-18.

Salazar-García, D.C., de Lugo Enrich, L.B., Álvarez García, H.J., Benito Sánchez, M., 2013b. Estudio diacrónico de la dieta de los pobladores antiguos de Terrinches (Ciudad Real) a partir del análisis de isótopos estables sobre restos óseos humanos. Rev. Esp. Antropol. Fís. 34, 6-14

Salazar-García, D.C., Aura, E., Olària, C., Talamo, S., Morales, J.V., Richards, M.P., 2014a. Isotope evidence for the use of marine resources in the Eastern Iberian Mesolithic J. Archaeol. Sci. 42, 231-240.

Salazar-García, D.C., Richards, M.P., Nehlich, O., Henry, A.G., 2014b. Dental calculus is not equivalent to bone collagen for isotope analysis: a comparison between carbon and nitrogen stable isotope analysis of bulk dental calculus, bone and dentine collagen from same individuals from the Medieval site of El Raval (Alicante,Spain). J. Archaeol. Sci. 47, 70-77.

Schmitt, A., 2005. Une nouvelle méthode pour estimer l'âge au décès des adultes à parti de la surface sacro-pelvienne iliaque. Bull. Mém. Soc. Anthropol. Paris 17, 89-101.

Schoeller, D.A., 1999. Isotope fractionation: why aren't we what we eat? J. Archaeol. Sci. 26, 667-673.

Schoeninger, M.J., De Niro, M., 1984. Nitrogen and carbon isotopic composition of bone collagen from marine and terrestrial animals. Geochim. Cosmochim. Act 48, 625-639.

Tovar, A., Blázquez, J.M., 1997. Historia de la Hispania Romana. Alianza, Madrid.

Van der Merwe, N.J., Vogel, J.C., 1978. ${ }^{13} \mathrm{C}$ content of human collagen as a measure of prehistoric diet in Woodland North America. Nature 276, 815-816.

Van Klinken, G.J., 1999. Bone collagen quality indicators for palaeodietary and radiocarbon measurements. J. Archaeol. Sci. 26, 687-695

Villegas Becerril, A., 2001. Gastronomía Romana y Dieta Mediterránea. El recetario de Apicio. Universidad de Córdoba, Córdoba.

Vives-Ferrándiz, J., 2008. Negotiating colonial encounters: hybrid practices and consumption in Eastern Iberia (8th-6th centuries BC). J. Mediterr. Archaeol. 21, 241-272.

Vizcaíno-Sánchez, J., 2007. La Presencia Bizantina en Hispania (siglos VI-VII), La documentación arqueológica. Monografías Históricas sobre la Antigüedad tardía VVIX. Universidad de Murcia, Murcia.

Zilhão, J., 2001. Radiocarbon evidence for maritime pioneer colonitation at the origins of farming in West Mediterranean Europe. Proc. Natl. Acad. Sci. U. S. A. 98, 14180-14185. 